\title{
Sistem Presensi Karyawan Berbasis Pengenalan Wajah Dengan Metode Support Vector Machine
}

\author{
David Setiyadi $^{1}$, Fauzun Atabiq ${ }^{1 *}$, dan Siti Aisyah ${ }^{1}$ \\ ${ }^{1}$ Politeknik Negeri Batam, Batam, Indonesia \\ *Email: atabiq@polibatam.ac.id
}

\begin{abstract}
Abstrak-Sistem presensi saat ini yang ada pada instansi ataupun perusahaan masih banyak yang menggunakan sistem manual. Disisi lain, perusahaan-perusahaan tersebut juga telah memiliki aplikasi pengelolaan SDM online. Oleh karena itu, untuk efektifitas dan pengembangan sistem, perlu dilakukan pengembangan sistem presensi manual tersebut menjadi sebuah sistem yang dapat diintegrasikan dengan sistem pengelolaan SDM. Untuk itu, penelitian ini mengusulkan pengembangan sistem presensi berbasiskan pengenalan wajah yang diintegrasikan dengan aplikasi pengelolaan SDM. Sistem yang dibangun merupakan sistem deteksi dan pengenalan menggunakan Support Vector Machine yang di kombinasikan dengan metode Histogram of oriented gradient. Hasil pengujian sistem presensi menunjukkan hasil recall sebesar $77,78 \%$, nilai spesifitas $32,22 \%$, akurasi sistem $72,78 \%$, dan kepresisian sistem mencapai $70,71 \%$.
\end{abstract}

Kata kunci: Presensi, Pengenalan Wajah, Support Vector Machine, Histogram of Oriented Gradients

\section{PENDAHULUAN}

DALAM pengelolaan Sumber Daya Manusia (SDM) di sebuah instansi atau perusahaan, pencatatan kehadiran karyawan merupakan salah satu faktor penting. Hal ini dikarenakan sistem pencatatan kehadiran terhubung dengan sistem pengelolaan SDM yang biasanya mencakup sistem penggajian, deadline pekerjaan, hak cuti karyawan, dan sebagainya. Untuk itu banyak perusahaan memilih untuk mengembangkan ataupun menggunakan perangkat berteknologi tinggi untuk diterapkan pada sistem pengelolaan SDMnya.

Sistem pengelolaan SDM pada umumnya tidak terlepas pada sistem identifikasi SDM. Sistem identifiksi dan pengenalan ini biasanya diterapkan pada sistem forensik, dan sistem keamanan, seperti pengaksesan ruangan, perangkat/data/dokumen, dan laman website melalui berbagai metode akses. Metode akses ini biasanya membutuhkan media sebagai identitas pengguna seperti sidik jari [1][2], telapak tangan [3], iris mata [4] dan pengenalan wajah [5]. Berbagai metode juga telah dikembangkan di beberapa penelitian seperti metode image quality enhancement, Deep Convolution Neural Networks (DCNN) [4], Wasserstein Convolutional Neural
Network [5], eigenface [6] dan metode lain yang bersesuaian dengan jenis media identitasnya.

Pada penelitian Wardoyo [6], dibangun sistem pengenalan wajah menggunakan algoritma eigenface melalui aplikasi komputer. Proses pengenalan wajah diawali dengan pengambilan gambar menggunakan webcam, yang kemudian informasi mentah dari pixel citra direpresentasikan dalam metode Principal Component Analysis (PCA). Hasil yang diperoleh menunjukkan sensivisitas $100 \%$, spesifitas 55,55\%, dan akurasi 69,33 \%. Namun, penelitian ini belum mengintegrasikan sistem dengan website, sehingga manajemen harus menuju lokasi presensi untuk mengambil data.

Oleh karena itu, penulis mengusulkan untuk mengembangkan sebuah sistem presensi karyawan suatu perusahaan melalui sistem pengenalan wajah menggunakkan metode Support Vector Machine. Harapannya dengan adanya penelitian ini akan terbangun sistem presensi karyawan yang terintegrasi dengan sistem pengelolaan SDM perusahaan, meningkatnya kesadaran karyawan dalam melakukan presensi dan terciptanya keterbukaan informasi pengelolaan SDM antara karyawan dengan manajemen perusahaan.

\section{TINJAUAN PUSTAKA}

Pada pengenalan citra wajah secara umum ada dua jenis, yaitu sistem image based dan feature based. Pada kedua sistem ini memiliki sistem pengolahan data yang berbeda, pertama image based yaitu informasi mentah dari pixel citra digunakan untuk merepresentasikan citra dalam metode tertentu, misalnya transformasi wavelet, menggunakan principal component analysis (PCA) untuk mengklasifikasi identitas citra. Sistem feature based digunakan fitur yang di ekstraksi dari komponen citra wajah seperti bagian mata, hidung, mulut. Selanjutnya, fitur-fitur tersebut dihubungkan dan dimodelkan secara geometris [7]. Cara kerja dari pengenalan wajah dengan menyesuaikan detail-detail wajah pengguna dengan citra yang ditangkapnya melalui sebuah kamera pendeteksi. Kemudian, citra wajah yang ditangkap dibandingkan dengan database citra wajah yang telah disimpan dan dianalisis seberapa tinggi tingkat kecocokannya. Metode yang digunakan dalam 
JOURNAL OF APPLIED ELECTRICAL ENGINEERING (E-ISSN: 2548-9682), VOL. 5, NO. 2, DEC 2021

penelitian ini adalah Histogram Of Oriented Gradient dan Support Vector Machine.

\section{A. Histogram of Oriented Gradient}

Metode Histogram of Oriented Gradients (HOG) yaitu mengubah citra RGB (Red, Green, Blue) menjadi citra skala keabu-abuan, kemudian dilanjutkan dengan menghitung nilai gradien setiap pixel. Setelah nilai gradien didapatkan, proses selanjutnya dengan cara penentuan jumlah bin orientasi yang akan digunakan dalam pembuatan histogram atau spatial orientation binning. Pada proses gradient compute, gambar training terbagi menjadi beberapa sel yang akan dikumpulkan menjadi block (ukuran yang lebih besar). Sedangkan pada proses normalisasi block sendiri digunakan perhitungan dari geometri R-HOG. Hal ini dilakukan karena terdapat block yang saling tumpang tindih. Proses ini berbeda dengan proses pembuatan histogram citra yang menggunakan nilai-nilai intensitas pixel dari suatu citra atau bagian tertentu dari citra [8]. Hasil dari algoritma HOG menjadi input dalam algoritma klasifikasi citra lain seperti Support Vector Machine (SVM). Tujuannya adalah untuk memperoleh hasil yang baik.

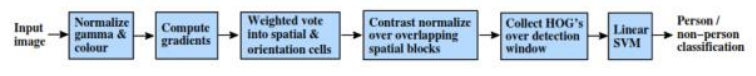

Gambar 1. Pemrosesan data menggunakan algoritma HOG

Pada Gambar 1 menjelaskan algoritma HOG dalam memproses sebuah gambar oleh Dalal dan Triggs. Navneet Dalal dan Bill Triggs dalam jurnalnya melakukan penelitian tentang $H O G$ untuk deteksi manusia. Dalam percobaan nya pada proses pertama normalisasi gamma \& colour mengevaluasi beberapa representasi input pixel antara lain grayscale, $R G B$, dan $L A B$ colour space opsional dengan persamaan gamma. Hasilnya yang paling baik menggunakan RGB dengan memberikan performa pada tingkat FPPW (dengan $1 \%$ pada $\left.10^{-4} \mathrm{FPPW}\right)(\mathrm{FPPW}=$ False Positives Per Window), merupakan ukuran yang digunakan untuk mendeteksi secara umum terkait dengan klasifikasi dan deteksi sebuah objek). Pada proses Compute gradient adalah dengan menghitung nilai gradien horizontal dan vertikal menggunakan Sobel Egde Detection.

\section{B. Support Vector Machine}

Vapnik (1995) untuk pertama kalinya mengenalkan metode Support Vector Machine (SVM) di COLT-92. Support vector machines (SVM) adalah seperangkat metode pembelajaran terarah (supervised learning) yang digunakan untuk melakukan proses klasifikasi dan regresi [9]. Salah satu yang membedakan metode klasifikasi SVM dengan metode lain adalah SVM untuk memperoleh ukuran margin yang maksimal adalah dengan menemukan hyperlane terbaik. Margin merupakan jarak antara hyperplane dengan titik terdekat dari masing-masing kelas yang ada [8].
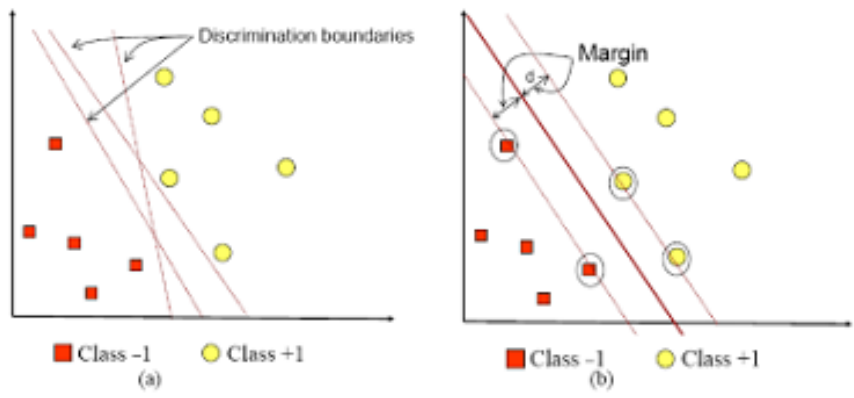

Gambar 2. SVM Hyperlane [8]

Gambar 2 SVM Hyperplane menunjukkan data beberapa pattern yang merupakan anggota dari dua buah class +1 dan 1. Untuk pattern yang warna merah (kotak) menyimbolkan pattern yang tergabung pada class -1 , sedangkan symbol warna kuning (lingkaran) menyimbolkan pattern pada class +1 . Pada gambar 2 juga menunjukan berbagai alternatif garis pemisah (discrimination boundaries). Usaha dalam menemukan garis (hyperplane) yang memisahkan kedua class tersebut disebut sebagai masalah klasifikasi. Dengan mengukur margin hyperplane dapat menemukan hyperplane pemisah terbaik antara kedua class tersebut dan mencari titik maksimalnya. Pattern yang paling dekat dengan margin ini disebut sebagai support vector. Hyperlane tebaik ditunjukan oleh Gambar 3 SVM Hyperplane berupa garis solid yang menunjukkan hyperplane yang terbaik, yaitu garis yang terletak tepat pada di antara kedua class, sedangkan untuk support vector sendiri adalah titik merah dan kuning yang ada di dalam lingkaran hitam tersebut. Dan inti dari proses pembelajaran pada Support Vector Machine (SVM) adalah usaha untuk mencari lokasi hyperplane. Pada proses learning-nya sendiri SVM mendapat inputan dari Feature HOG [8].

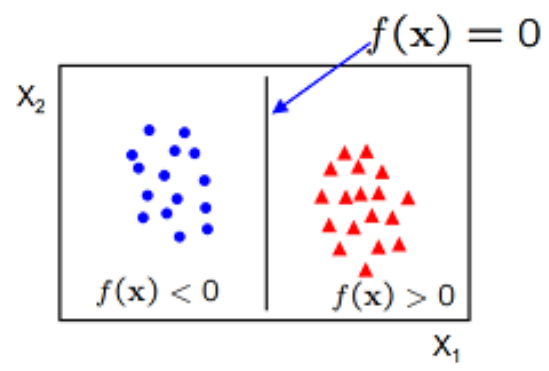

Gambar 3. Bobot Positif dan Negatif pada Linear Classifier [10]

Pada Gambar 3 menjelaskan tentang klasifikasi SVM Linier untuk memisahkan vector dalam dimensi 2. Solusi Soft margin digunakan untuk mengatasi masalah dalam mencari $w$ terbaik. Pada pelatihan data dan feature SVM diambil dengan mengambil sampel positif dan negative dari HOG Descriptor. Sampel positif artinya terdapat objek seperti yang di tampilkan sedangkan negative artinya tidak terdapat objek. 


\section{METODE}

\section{A. Deskripsi Sistem}

Pada pembuatan aplikasi presensi dibutuhkan perancangan perangkat lunak dan perangkat keras. Pada perancangan perangkat lunak terdiri dari 3 bagian yaitu aplikasi, database dan website. Sedangkan dari perangkat keras sistem akan dibuat dengan meletakan kamera di meja dekat pintu masuk karyawan. Kamera akan menangkap wajah pegawai yang melakukan presensi dengan memposisikan wajah di depan kamera yang telah disediakan. Selanjutnya data hasil kamera diproses dengan pengenalan wajah untuk mendapat data unik id karyawan. Setelah itu data unik id dan waktu kedatangan atau pulang dikirim ke database server dengan simulasi localhost di komputer. Data pada server kemudian diolah untuk menghasilkan informasi mengenai presensi karyawan.

\section{B. Pengumpulan Data}

Tahap pertama dari penelitian ini adalah pengumpulan data. Tahap pengumpulan data adalah alat bantu yang digunakan oleh peneliti untuk memperoleh informasi yang dipakai pada proses penelitian. Pada tahap ini juga menyiapkan perangkat webcam yang digunakan untuk mengambil data citra. Untuk data karyawan telah tersedia pada database server. Penulis meminta ijin untuk mengakses database. Dengan menggunakan query (bahasa pemrograman Sql untuk melakukan permintaan data) untuk mendapatkan data karyawan. Kemudian data foto di kumpulkan dalam satu folder yang akan digunakan untuk proses learning. Foto yang digunakan adalah foto Close up yang diambil menggunakan webcam yang sama dengan webcam yang digunakan untuk pengujian alat.

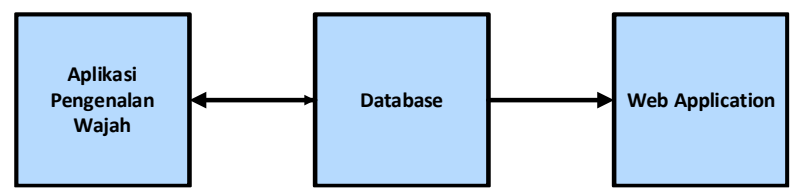

Gambar 4. Blok Diagram Sistem Presensi

\section{Perancangan Software}

Perancangan software pada penelitian ini adalah proses pengembangan sistem presensi karyawan yang meliputi perancangan antarmuka dan proses pengenalan wajah. Pada perancangan software tahapan pertama perancangan block diagram seperti yang ditunjukan Gambar 4 dibawah ini.

Gambar 5 menjelaskan sistem yang digunakan untuk membangun aplikasi presensi. Aplikasi pengenalan wajah adalah alat yang digunakan untuk proses deteksi dan pengenalan wajah dibangun menggunakan framework python kemudian aplikasi presensi terhubung dengan database melalui koneksi python ke local database postgres. Database adalah aplikasi yang digunakan untuk menampung data pengujian. Aplikasi mengirim data ke presensi ke database, apabila data sudah ada maka database akan memberikan respon kepada aplikasi pengenalan wajah. Database digunakan adalah postgresql, karena hanya postgresql yang dapat terhubung langsung dengan framework Web yang digunakan. Web
Application adalah aplikasi yang digunakan penulis untuk menampilkan data hasil presensi dan alat pengelolaan SDM atau biasa disebut system ERP. Untuk Web application nya sendiri dibangun menggunakan framework Odoo.

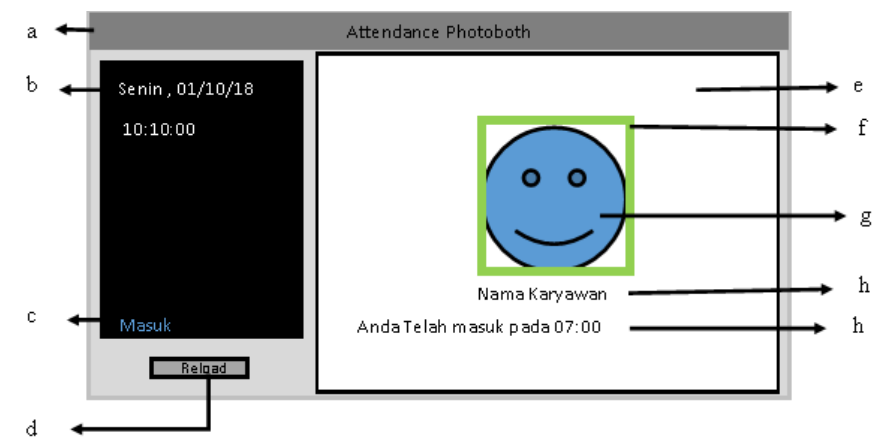

Gambar 5. Design Interface Aplikasi Presensi

Gambar 5 Design Interface Aplikasi Presensi menjelaskan desain antarmuka pada aplikasi presensi berikut poin-poin penjelasannya:

1) Attendance Photobooth : merupakan judul form aplikasi yang dibangun menggunakan python.

2) Tanggal dan jam : pada bagian kiri atas menunjukan tanggal dan jam saat ini.

3) Masuk : merupakan status presensi untuk catat masuk atau pulang (Default sebelum pukul 12:00 otomatis sebagai presensi masuk, setelah pukul 12:00 sebagai Keluar).

4) Tombol Reload : digunakan untuk memperbarui database wajah dan training ulang database wajah yang ada pada directory database.

5) Frame aplikasi : menampilkan gambar realtime dari perangkat webcam Logitech C270.

6) Kotak hijau : untuk menandai posisi wajah dalam gambar, bisa lebih dari satu.

7) Area Wajah : wajah karyawan yang melakukan presensi.

8) Nama karyawan : Nama dari karyawan yang melakukan presensi ditampilkan di bawah kotak wajah.

9) Info waktu presensi : menampilkan info kapan terakhir masuk atau pulang apabila telah dicatat.

Aplikasi ini dibuat menggunakan bahasa Python, untuk penulisan program penulis menggunakan Sublime-Text 3. Pada tampilan interface dirancang menggunakan Python Tkinter. Tkinter merupakan module pendukung dalam membuat GUI (antarmuka) yang digunakan oleh Bahasa pemrograman python. Library Open CV digunakan untuk menampilkan hasil pemrosesan ke dalam canvas di antarmuka aplikasi. Proses pengenalan wajah dimulai dari pengambilan gambar melalui webcam kemudian dilanjutkan dengan penentuan posisi wajah menggunakan HOG, lalu dengan facial landmark untuk memposisikan wajah simetris selanjutnya dengan SVM untuk memprediksi karyawan yang melakukan presensi. Untuk sistem kerja program ini secara ringkas ditujunjukkan oleh Gambar 6. 
Pada Gambar 6 menjelaskan tentang proses pengenalan wajah, proses pertama webcam aktif untuk menangkap citra. Tahap selanjutnya proses deteksi wajah, untuk mengenali wajah dalam gambar adalah dengan menemukan bagian gambar yang paling terlihat mirip dengan pola wajah menggunakan Feature HOG dan SVM. Apabila dikenali sebagai wajah maka dilanjutkan ke proses berikutnya. Bila tidak maka akan kembali ke tahapan awal. Tahapan selanjutnya Encoding 128D Measurement pada proses ini image di encoding menjadi bentuk vektor yang berisi 128D[11]. Dengan menggunakan identifikasi Euclidean distance image hasil encoding di bandingkan dengan image pada database yang telah di-training dan disimpan dalam file format numpy array. Bila menemukan nilai terdekat atau maksimal level perbedaan 0,5 maka data dikirim ke database server data diolah agar menghasilkan informasi yang bisa digunakan sebagai laporan kehadiran.

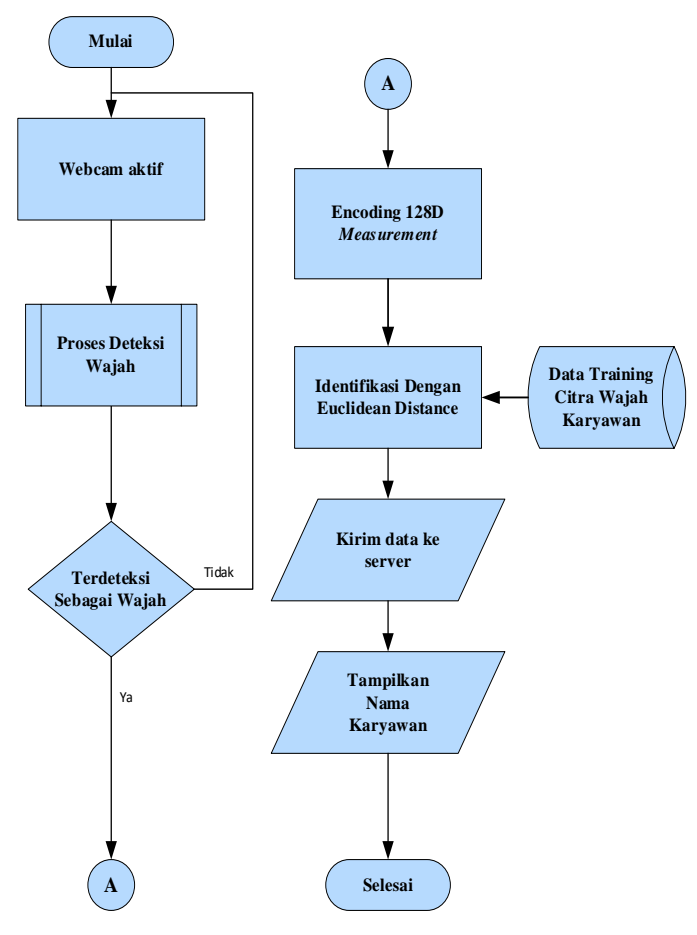

Gambar 6. Diagram Alir Proses Pengenalan Wajah

1) Proses Deteksi Wajah dengan HOG

Proses deteksi wajah menggunakan HOG dijelaskan oleh diagram alir pada Gambar 7. Gambar 7 menjelaskan tahapan dari Akuisisi Citra sampai terdeteksi sebagai Wajah. Untuk Proses ini menggunakan feature descriptor Histogram of Oriented Gradient dan SVM. Tahapannya sebagai berikut:

a) Tahap pertama yaitu akuisisi citra, citra diperoleh dari memicu webcam menyala.

b) Setelah akuisisi citra tahap selanjutnya yaitu Resize Frame.

$$
\left(\begin{array}{l}
x^{\prime} \\
y^{\prime}
\end{array}\right)=\left(\begin{array}{cc}
s_{x} & 0 \\
0 & s y
\end{array}\right) \cdot\left(\begin{array}{l}
x \\
y
\end{array}\right)
$$

Resize Frame yaitu memperkecil ukuran gambar dengan fungsi scaling terhadap sumbu $\mathrm{x}$ dan y dengan faktor $s_{x}$ dan $s_{y}$ [12]. Disini gambar dengan resolusi $1280 \times 720$ pixel di resize 0,25 menjadi $320 \times 180$ pixel. Tujuan resize gambar ini agar mempercepat proses pengenalan wajah.

c) Kemudian normalisasi warna, membuat warna menjadi grayscale. Transformasi dalam ruang RGB konversi dari warna RGB ke skala abu-abu.

$$
\begin{aligned}
& \text { RGB [ A] to Gray }=\mathrm{L}= \\
& 0,299 \cdot \mathrm{R}+0,587 \cdot \mathrm{G}+0,114 \cdot \mathrm{B}
\end{aligned}
$$

d) Setelah itu menghitung nilai gradient pada tiap-tiap pixel. Ma

Magnitude $($ besar gradient $)=g=\sqrt{g_{x}^{2}+g_{y}^{2}}$

Orientasi gradient (dalam sudut) $=\theta=\arctan \frac{g_{y}}{g_{x}}$

e) Dilanjutkan dengan spatial orientation binning atau menentukan bin orientasi. Gambar dikelompokan dalam ruang yang lebih dikecil disebut sel. Angka tetap dalam bins didapat dari sudut gradient yang dibagi oleh histogram orientasi. Besar gradient dan orientasi digunakan untuk vote ke dalam histogram orientasi. Penulis membuat histogram gradien dalam $8 \times 8$ sel. Histogram berisi 9 bins yang sesuai dengan sudut $0,20,40 \ldots 160$.

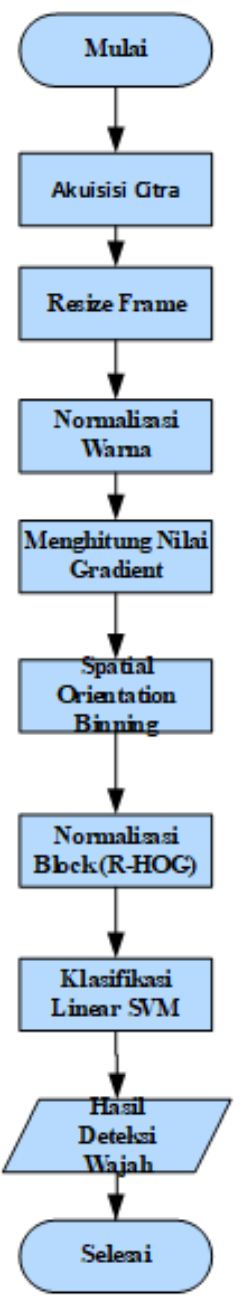

Gambar 7. Diagram Alir Proses Deteksi Wajah 


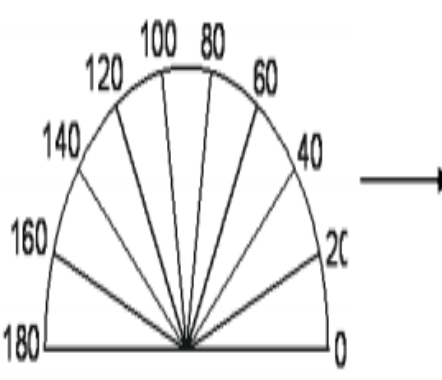

(a)

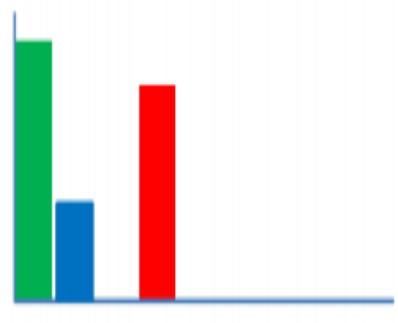

1030507090110130150170

(b)
Gambar 8. (a) Sudut Gradient, (b) Grafik Histogram pada set [8]

Gambar 8 masing-masing menjelaskan (a) adalah sudut gradient, nilai magnitude dalam suatu citra, sedangkan (b) adalah grafik histogram dalam setiap sel pada sebuah gambar.

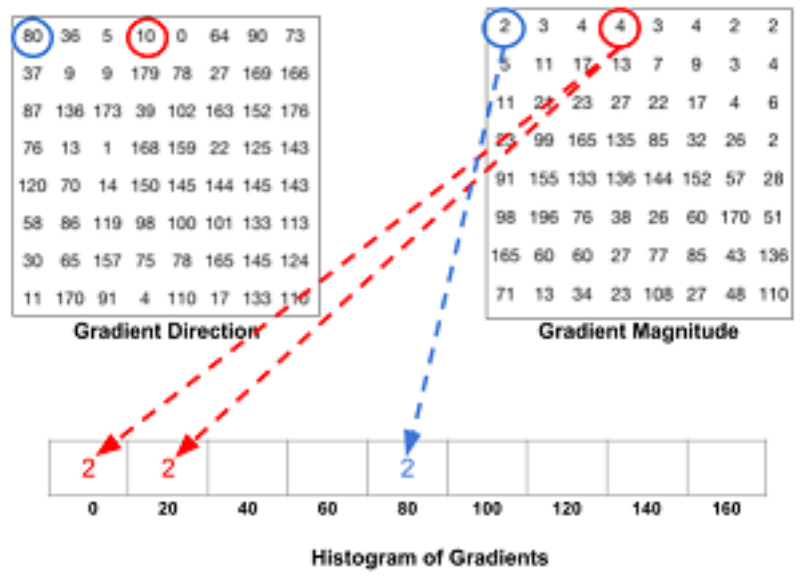

Gambar 9. Contoh perhitungan menentukan bin orientasi [8]

Gambar 9 menjelaskan tentang proses perhitungan dalam menentukan bin orientasi, data array sebelah kiri adalah arah gradient (direction) sedangkan data sebelah kanan merupakan gradient magnitude. Posisi bin dipilih berdasarkan arah sedangkan nilai bin dipilih berdasarkan magnitude. Warna biru dengan gradient direction 80 dan gradient magnitude 2 maka berada pada posisi bin ke 5 dengan nilai 2. Sedangkan yang dilingkari merah nilai gradient direction 10, dan nilai gradient magnitude 4, karena 10 berada di antara 0 dan 20 maka gradient mengisi 2 bin.

f) Tahap selanjutnya normalisasi block. Dalam penelitian ini geometri yang digunakan adalah R-HOG. R-HOG umumnya kotak persegi, diwakili oleh tiga parameter: jumlah sel per blok, jumlah pixel per sel, dan jumlah channel per histogram sel. Dalal dan Triggs, dalam jurnal HOG untuk deteksi manusia, parameter optimal ditemukan menjadi empat sel 8x8 pixel per blok (16x16 pixel per blok) dengan 9 channel histogram. Menghitung normalisasi blok yaitu dengan cara menormalisasi respons kontras secara keseluruhan dan mengambil kelompok sel. Hal ini dilakukan dengan cara mengakumulasikan ukuran histogram dari grup tiap-tiap sel yang disebut blok. Untuk menormalisasi setiap sel dalam blok menggunakan hasil proses, berikut adalah penghitungan histogram pada blok:

$$
L 2-\text { norm }: v \rightarrow v / \sqrt{\|v\|_{2}^{2}+\varepsilon^{2}}
$$

g) Tahapan terakhir adalah klasifikasi linear svm dan proses deteksi wajah. Dengan menggunakan soft constrain $(\mathrm{C}=0,01)$ untuk pelatihan SVM. Dataset yang digunakan untuk pelatihan, terdiri dari 2825 gambar yang diperoleh dari dataset LFW yang disediakan oleh Davis King, penulis Dlib. Kemudian menggunakan klasifikasi sliding window untuk deteksi posisi wajah dalam sebuah gambar dengan mencari bobot positif. Dengan training data $\left(x_{i}, y_{i}\right)$ for $i=$ $1 \ldots \mathrm{N}$,dengan $x_{i} \in \mathbb{R}^{d}$ dan $y_{i} \in\{-1,1\}$, pembelajaran klasifikasi $f(\mathrm{x})$.

$$
\begin{gathered}
f\left(x_{i}\right)= \begin{cases}\geq 0 & y_{i}=+1 \\
<0 & y_{i}=-1\end{cases} \\
f(x)=w^{T} x+b
\end{gathered}
$$

Dari rumus (6) dan gambar 4 Bobot Positif dan Negatif pada Linear Classifier maka proses pembelajaran svm dirumuskan dalam persamaan (7).

1) Proses Encoding 128 Dimension measurement

Pada proses ini bertujuan untuk menghasilkan 128 pengukuran pada setiap citra wajah yang dideteksi. Gagasan untuk mengurangi data mentah yang rumit seperti data citra ke dalam daftar angka yang dihasilkan machine learning telah banyak dilakukan penelitian. Pendekatan yang penulis gunakan dalam penelitian ini yang ditemukan oleh Schroff (2015)[12].

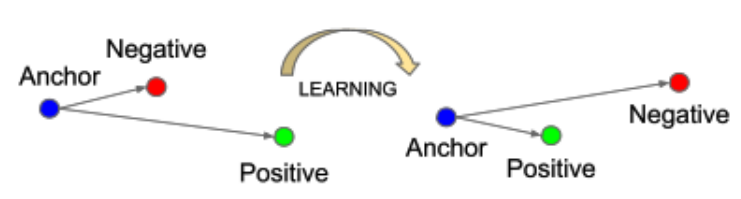

Gambar 10. Triplet Loss minimizes the distance

Gambar 10. Triplet loss minimizes the distance menjelaskan tentang proses learning bertujuan untuk mengurangi jarak antara anchor dan positif, dan maksimal jarak antara anchor dan negative. Embedding direpresentasikan dengan $f(x) \in$ $\mathbb{R}^{d}$. Embed citra $x$ kedalam $d$-dimensi Euclidean space. Facenet (Schroff) menggunakan 128 dimensi dan membuat model yang memetakan setiap wajah manusia secara umum. Ketika diberikan citra input model akan memberikan 128 byte data vektor numerik. Titik-titik embedding ini mudah dibandingkan dengan mengukur jarak Euclidean.

2) Proses Identifikasi dengan Euclidean Distance

Untuk identifikasi hasil vector citra test dengan vector citra database dengan mencari jarak terdekat antara vector citra test dengan vector citra database. Jarak (distance) ini digunakan untuk menentukan tingkat kesamaan dalam dua fitur vector [13]. Penulis menggunakan Euclidean distance dalam menghitung kesamaan 2 vektor. Akar kuadrat dari perbedaan 2 vektor dihitung dengan Euclidean distance. Pada citra wajah orang yang sama Euclidean distance 
cenderung kecil. Untuk identifikasi diambil dari nilai Euclidean distance terendah dengan batas toleransi 0.5.

$$
d_{y}=\sqrt{\sum_{k=1}^{n}\left(x_{i k}+x_{j k}\right)^{2}}
$$

Contoh pada perhitungan menunjukkan 2 citra wajah:

$\mathrm{A}=[0,3,4,5]$

$\mathrm{B}=[7,6,3,-1]$

$\mathrm{C}=[1,3,4,5]$

Dengan C sebagai vektor test dan vektor A, vektor B merupakan database.

$$
\begin{gathered}
d_{A B}=\sqrt{(0-7)^{2}+(3-6)^{2}+(4-3)^{2}+\left(5-(-1)^{2}\right.} \\
d_{A B}=\sqrt{(49+9+1+36}=9,747 \\
d_{A C}=\sqrt{(0-1)^{2}+(3-3)^{2}+(4-4)^{2}+(5-5)^{2}} \\
d_{A C}=\sqrt{(1+0+0+0}=\sqrt{1}
\end{gathered}
$$

Dari hasil perhitungan diperoleh jarak citra paling kecil yaitu $\sqrt{1}$, maka hasil identifikasi menyimpulkan Vector A lebih mirip terhadap Vector $\mathrm{C}$ namun dari nilai batas toleransi di atas 0,5 maka image dianggap bukan bagian dari karyawan

\section{Pembuatan Program}

Langkah selanjutnya yaitu pembuatan program. Pembuatan program adalah proses menerjemahkan dari diagram alir ke dalam suatu bahasa pemrograman. Bahasa pemrograman python dipilih dalam penelitian ini karena bersifat open source dan dapat dijalankan pada sistem operasi Ubuntu. Sedangkan untuk penulisan program penulis menggunakan software Sublime-Text, karena memiliki fitur indent tab yang dibutuhkan oleh python.

\section{E. Instalasi}

Instalasi adalah alat perlengkapan yang di pasang pada posisi tertentu dan siap untuk digunakan.

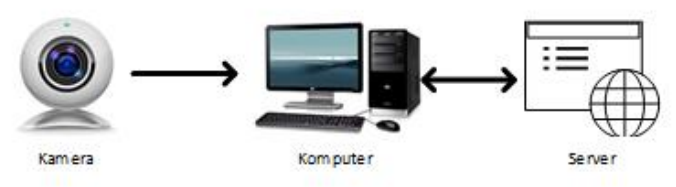

Gambar 11. Instalasi Perangkat

Gambar 11 Instalasi Perangkat menjelaskan tentang perancangan perangkat yang akan dibuat. Perangkat untuk pengembangan sistem ini menggunakan kamera webcam Logitech C270 dan Komputer. Kamera dihubungkan ke komputer melalui kabel USB, komputer digunakan untuk memproses data hasil dari kamera. Selanjutnya data yang telah diproses berupa data tanggal dan id karyawan dikirim ke server dan server memberikan respons berupa peringatan apabila karyawan tersebut telah melakukan presensi sebelumnya.

\section{F. Metode Pengambilan Data}

Pada pengambilan data posisi kamera menghadap ke arah objek. Di penelitian ini, dilakukan pengambilan data dalam beberapa tahap yang meliputi:

1) Pengujian kemampuan deteksi berdasarkan jarak.
Pengujian ini bertujuan untuk mengetahui jangkauan aplikasi mendeteksi wajah dan jarak ideal dalam melakukan presensi. Pengujian kemampuan deteksi berdasarkan jarak dilakukan mulai dari $10 \mathrm{~cm}$ sampai $110 \mathrm{~cm}$ dengan posisi kamera mengarah ke objek dan wajah posisi menghadap ke kamera.

2) Pengujian kemampuan deteksi berdasarkan posisi kemiringan wajah.

Pengujian kemampuan deteksi berdasarkan posisi wajah bertujuan untuk mendapatkan posisi wajah yang ideal dalam melakukan proses presensi. Posisi wajah yang diuji adalah posisi Pitch, Yaw, dan Roll dengan range antara 50 derajat sebelum sampai 50 derajat sesudah. Dengan posisi nol derajat adalah posisi di depan kamera dengan posisi wajah menghadap kamera seperti ditunjukkan gambar 15 Posisi wajah. Pengujian dilakukan dengan mengarahkan kamera ke objek dan dengan menggerakkan posisi kepala.

3) Pengujian tingkat keberhasilan sistem presensi karyawan berbasis pengenalan wajah dengan metode support vector machine dengan cara mengintegrasikan hasil dari proses pengenalan wajah dengan database system pengelolaan SDM milik perusahaan. Sedangkan untuk tingkat keberhasilan pengenalan wajah parameter yang digunakan antara lain:

a) Recall

Recall (sensivisitas) atau True positif rate adalah keberhasilan sistem dalam menemukan kembali informasi yang diperoleh dan dihitung dengan rumus.

b) Spesifitas

$$
\text { Recall }=\frac{T P}{T P+F N} \times 100 \%
$$

Spesifitas atau False positif rate atau kekhususan merupakan nilai yang menunjukkan kesalahan pada saat proses identifikasi.

$$
\text { Spesifitas }=\frac{F P}{T P+F N} \times 100 \%
$$

\section{c) Akurasi}

Akurasi adalah tingkat kedekatan antara nilai aktual dengan nilai prediksi. Dan keakurasian sistem pengenalan dilakukan dengan membagi jumlah klasifikasi benar dengan total pengujian.

d) Presisi

$$
\text { Akurasi }=\frac{T P+T N}{T P++F P+T N+F N} \times 100 \%
$$

Presisi adalah tingkat ketepatan antara nilai yang diprediksi benar dengan tepat dengan nilai total prediksi benar dan dihitung dengan rumus [14].

$$
\text { Presisi }=\frac{T P}{T P+F P} \times 100 \%
$$

Keterangan:

a. TP $($ true positive $)=$ Citra wajah yang dapat di identifikasi dan benar datanya ada pada database (pengujian benar).

b. FP (false positif) = Citra wajah yang di identifikasi benar namun pada database merupakan data salah (salah mengidentifikasi).

c. TN (true negative) = Citra wajah seharusnya di identifikasi salah dan diidentifikasi salah (pengujian benar). 
d. FN (false negative) = Citra wajah yang seharusnya di identifikasi benar namun salah dalam mengidentifikasi.

\section{HASIL DAN PEMBAHASAN}

\section{A. Pengujian Kemampuan Berdasarkan Jarak}

Untuk mengetahui jarak ideal dalam melakukan presensi, maka dilakukan pengujian jarak jangkauan terhadap kemampuan mengenali wajah dengan menggunakan Aplikasi Presensi. Pengukuran dilakukan dari jarak $10 \mathrm{~cm}$ karena bila dibawah $10 \mathrm{~cm}$ tidak dapat dideteksi sebagai wajah, pengujian dilakukan dengan objek yang sama. Hasil pengujian sebagian di tampilkan pada Tabel I.

TABEL I

PENGUJIAN DETEKSI JARAK

\begin{tabular}{ccl}
\hline & PENGUJIAN DETEKSI JARAK \\
\hline \hline Hari ke- & Suhu $\left({ }^{\circ} \mathrm{C}\right)$ & Kelembaban $(\%)$ \\
\hline 1 & 10 & Tidak terdeteksi \\
2 & 20 & Tidak terdeteksi \\
3 & 30 & Terdeteksi \\
4 & 40 & Terdeteksi \\
5 & 50 & Terdeteksi \\
6 & 60 & Terdeteksi \\
7 & 70 & Terdeteksi \\
8 & 80 & Terdeteksi \\
9 & 90 & Terdeteksi \\
10 & 100 & Tidak Terdeteksi \\
11 & 110 & Tidak Terdeteksi \\
\hline \hline
\end{tabular}

Dari data tabel I dapat dilihat jarak ideal dalam melakukan presensi yaitu antara $30 \mathrm{~cm}-90 \mathrm{~cm}$. Jarak ini dijadikan referensi untuk melakukan proses presensi

\section{B. Pengujian Kemampuan Deteksi Berdasarkan Kemiringan}

Pengujian kemampuan deteksi berdasarkan kemiringan bertujuan untuk mendapatkan posisi wajah yang ideal dalam melakukan proses presensi. Ada tiga jenis posisi kemiringan yang diambil datanya antara lain posisi Pitch, Roll, dan Yaw.

TABLE II

Hasil Pengujian Terhadap Posisi Pitch, Roll, Yaw

\begin{tabular}{rclll}
\hline \hline No & $\begin{array}{c}\text { Sudut } \\
\left({ }^{\circ}\right)\end{array}$ & \multicolumn{1}{c}{ Pitch } & \multicolumn{1}{c}{ Roll } & \multicolumn{1}{c}{ Yaw } \\
\hline 1 & -50 & Tidak Terdeteksi & Tidak Terdeteksi & Tidak Terdeteksi \\
2 & -40 & Tidak Terdeteksi & Terdeteksi & Tidak Terdeteksi \\
3 & -30 & Terdeteksi & Terdeteksi & Terdeteksi \\
4 & -20 & Terdeteksi & Terdeteksi & Terdeteksi \\
5 & -10 & Terdeteksi & Terdeteksi & Terdeteksi \\
6 & 0 & Terdeteksi & Terdeteksi & Terdeteksi \\
7 & 10 & Terdeteksi & Terdeteksi & Terdeteksi \\
8 & 20 & Terdeteksi & Terdeteksi & Terdeteksi \\
9 & 30 & Terdeteksi & Terdeteksi & Terdeteksi \\
10 & 40 & Terdeteksi & Terdeteksi & Tidak Terdeteksi \\
11 & 50 & Tidak Terdeteksi & Tidak Terdeteksi & Tidak Terdeteksi \\
\hline \hline
\end{tabular}

Dari data hasil pengujian kemiringan pada Tabel II diperoleh bahwa sistem mampu mendeteksi dan mengenali wajah dengan posisi terhadap Roll antara range - 40 derajat atau 40 derajat ke arah kiri sampai 40 derajat ke arah kanan. Posisi
Yaw atau terhadap sumbu tegak lurus dengan gravitasi antara 30 derajat sampai 30 derajat. Sedangkan pada posisi Pitch alat mampu mendeteksi dari -30 derajat atau posisi menunduk sampai 40 derajat posisi menengadah.

TABLE III

STANDAR RANGE EFFECTIVITIES SISTEM

\begin{tabular}{ll}
\hline \hline \multicolumn{1}{c}{ Sudut Pengujian } & \multicolumn{1}{c}{ Kriteria } \\
\hline $0^{\circ} \mathrm{s} / \mathrm{d} 30^{\circ}$ dan $0^{\circ} \mathrm{s} / \mathrm{d}-30^{\circ}$ & Efektif \\
$30^{\circ} \mathrm{s} / \mathrm{d} 50^{\circ}$ dan $-30^{\circ} \mathrm{s} / \mathrm{d}-50^{\circ}$ & Tidak Efektif \\
Di atas $50^{\circ}$ dan Di bawah $-50^{\circ}$ & Sangat Tidak Efektif \\
\hline \hline
\end{tabular}

Dari tabel III diperoleh standar range efektivitas sistem antara lain : efektif apabila diuji pada sudut $0^{\circ} \mathrm{s} / \mathrm{d} 30^{\circ}$ dan $0^{\circ}$ $\mathrm{s} / \mathrm{d}-30^{\circ}$, tidak efektif apabila diuji pada range $30^{\circ} \mathrm{s} / \mathrm{d} 50^{\circ}$ dan $-30^{\circ} \mathrm{s} / \mathrm{d}-50^{\circ}$, sangat tidak efektif apabila diuji pada range di atas $50^{\circ}$ atau di bawah $50^{\circ}$.

\section{Pengujian Presensi}

Pengujian Presensi bertujuan untuk menguji kestabilan sistem saat digunakan untuk proses presensi karyawan dengan melakukan simulasi presensi. Data diambil dengan data karyawan yang ada di basis data dan data bukan karyawan yang tidak ada di basis data.

Penjelasan istilah yang digunakan sebagai berikut:

1) TP atau True Positif adalah Prediksi benar pada aktual Benar.

2) FP atau False Positif adalah Prediksi benar pada aktual Salah.

3) FN atau False Positif adalah Prediksi salah pada aktual Benar.

4) TN atau True Negatif adalah Prediksi salah pada aktual salah

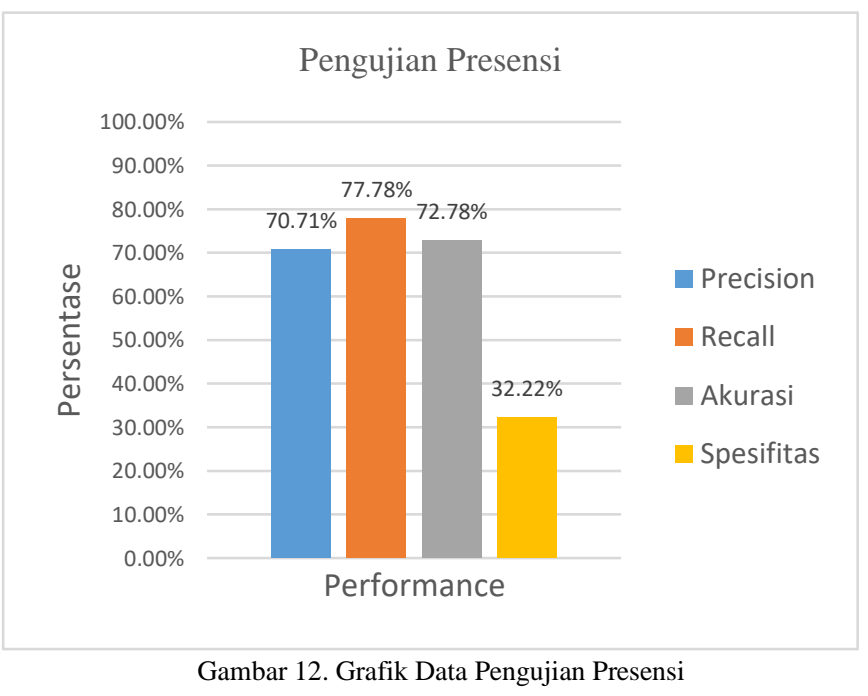

Gambar 12 menampilkan data hasil pengujian presensi. Pengujian dilakukan dengan karyawan dan visitor, di mana untuk karyawan datanya telah dimasukkan dalam database sedangkan visitor datanya tidak. Pengujian diperoleh Precision 70,71\%, Recall 77,78\%, Akurasi 71,78\%, dan Spesifitas 32.22 $\%$. Pada pengujian presensi karyawan False Negative atau salah deteksi pada data yang telah di register sebayak 20 dari 90 data. Pada pengujian presensi Visitor diperoleh False positif atau salah deteksi pada data False sebesar 29 dari total 90 pengujian. 
TABLE IV

PENGUJian SIMULASI PRESENSI KARYAWAN

\begin{tabular}{cccccccccccc}
\hline \hline \multirow{2}{*}{ No } & \multirow{2}{*}{ Nama } & 1 & 2 & 3 & 4 & 5 & 6 & 7 & 8 & 9 & 10 \\
\hline 1 & Karyawan 1 & TP & FN & TP & TP & TP & FN & TP & TP & FN & TP \\
2 & Karyawan 2 & FN & TP & TP & TP & TP & TP & FN & TP & TP & FN \\
3 & Karyawan 3 & TP & TP & TP & FN & FN & TP & TP & TP & FN & TP \\
4 & Karyawan 4 & TP & TP & TP & TP & TP & TP & TP & FN & TP & TP \\
5 & Karyawan 5 & TP & TP & TP & TP & FN & TP & TP & TP & FN & FN \\
6 & Karyawan 6 & TP & TP & TP & TP & TP & TP & TP & TP & TP & TP \\
7 & Karyawan 7 & FN & TP & TP & TP & TP & FN & TP & TP & TP & FN \\
8 & Karyawan 8 & TP & TP & TP & TP & FN & TP & TP & TP & TP & TP \\
9 & Karyawan 9 & FN & TP & TP & TP & FN & TP & TP & TP & FN & TP \\
\hline \hline
\end{tabular}

Dari hasil pengujian simulasi presensi karyawan yang semuanya telah diregister diperoleh identifikasi benar atau nilai $\mathrm{TP}=70$ dan identifikasi salah atau $\mathrm{FN}=20$.

TABLE V

\begin{tabular}{|c|c|c|c|c|c|c|c|c|c|c|c|}
\hline \multicolumn{12}{|c|}{ PENGUJIAN SIMULASI PRESENSI BUKAN KARYAWAN } \\
\hline \multirow{2}{*}{ No } & \multirow[b]{2}{*}{ Nama } & \multicolumn{10}{|c|}{ Pengujian Ke } \\
\hline & & 1 & 2 & 3 & 4 & 5 & 6 & 7 & 8 & 9 & 10 \\
\hline 1 & Visitor 1 & FP & FP & FP & FP & $\mathrm{TN}$ & FP & FP & FP & FP & $\mathrm{TN}$ \\
\hline 2 & Visitor 2 & FP & FP & $\mathrm{TN}$ & $\mathrm{TN}$ & $\mathrm{TN}$ & $\mathrm{TN}$ & $\mathrm{TN}$ & $\mathrm{TN}$ & $\mathrm{TN}$ & $\mathrm{TN}$ \\
\hline 3 & Visitor 3 & $\mathrm{TN}$ & $\mathrm{TN}$ & TN & $\mathrm{TN}$ & $\mathrm{TN}$ & $\mathrm{TN}$ & $\mathrm{TN}$ & $\mathrm{TN}$ & TN & $\mathrm{TN}$ \\
\hline 4 & Visitor 4 & $\mathrm{TN}$ & $\mathrm{TN}$ & FP & FP & FP & $\mathrm{TN}$ & $\mathrm{TN}$ & $\mathrm{TN}$ & FP & FP \\
\hline 5 & Visitor 5 & $\mathrm{TN}$ & $\mathrm{TN}$ & FP & FP & FP & FP & FP & FP & FP & FP \\
\hline 6 & Visitor 6 & $\mathrm{TN}$ & $\mathrm{TN}$ & TN & $\mathrm{TN}$ & $\mathrm{TN}$ & $\mathrm{TN}$ & $\mathrm{TN}$ & $\mathrm{TN}$ & TN & $\mathrm{TN}$ \\
\hline 7 & Visitor 7 & $\mathrm{TN}$ & $\mathrm{TN}$ & TN & $\mathrm{TN}$ & $\mathrm{TN}$ & FP & $\mathrm{TN}$ & $\mathrm{TN}$ & $\mathrm{TN}$ & $\mathrm{TN}$ \\
\hline 8 & Visitor 8 & $\mathrm{TN}$ & $\mathrm{TN}$ & TN & $\mathrm{TN}$ & $\mathrm{TN}$ & $\mathrm{TN}$ & $\mathrm{TN}$ & $\mathrm{TN}$ & TN & $\mathrm{TN}$ \\
\hline 9 & Visitor 9 & $\mathrm{TN}$ & $\mathrm{TN}$ & $\mathrm{TN}$ & FP & FP & $\mathrm{TN}$ & FP & FP & FP & $\mathrm{TN}$ \\
\hline
\end{tabular}

Dari hasil pengujian simulasi presensi bukan karyawan atau tamu yang datanya tidak ada di database diperoleh identifikasi benar atau nilai $\mathrm{TN}=61$ dan identifikasi salah atau $\mathrm{FP}=29$.

$$
\begin{aligned}
& \text { Recall }=\frac{70}{70+20} \times 100 \%=77,78 \% \\
& \text { Spesifitas }=\frac{29}{70+20} \times 100 \%=32,22 \% \\
& \text { Akurasi }=\frac{70+61}{70+61+29+20} \times 100 \%=77,78 \% \\
& \text { Presisi }=\frac{70}{70+29} \times 100 \%=70,71 \%
\end{aligned}
$$

\section{KESIMPULAN}

Berdasarkan analisa dari pengujian pengenalan wajah dalam aplikasi presensi maka dapat disimpulkan bahwa Hasil pengujian pengambilan gambar berdasarkan jarak menunjukkan hasil yang paling baik di antara $30 \mathrm{~cm}-90 \mathrm{~cm}$. Berdasarkan pengujian kemampuan berdasarkan kemiringan didapat bahwa sistem mampu mendeteksi dan mengenali wajah dengan posisi terhadap Roll antara range -40 derajat atau 40 derajat ke arah kiri sampai 40 derajat ke arah kanan. Posisi Yaw atau terhadap sumbu tegak lurus dengan gravitasi antara -30 derajat sampai 30 derajat. Sedangkan pada posisi Pitch alat mampu mendeteksi dari -30 derajat atau posisi menunduk sampai 40 derajat posisi menengadah. Pada pengujian presensi didapat sistem dapat menemukan kembali informasi dengan baik ditunjukkan dengan hasil recall 77,78\%, tingkat kesalahan saat proses identifikasi atau spesifitas 32,22\%, kemudian tingkat kedekatan nilai aktual dan prediksi atau akurasi 77,78\%, dan tingkat ketepatan nilai yang diprediksi benar dengan tepat atau presisi $70,71 \%$.

\section{REFERENSI}

[1] E. Rahmawati et al., "Digital signature on file using biometric fingerprint with fingerprint sensor on smartphone," Proceedings IES-ETA 2017 International Electronics Symposium on Engineering Technology and Applications, vol. 2017-December, pp. 234-238, Dec. 2017, doi: 10.1109/ELECSYM.2017.8240409.

[2] W. Jiang, X. Wang, X. Song, Q. Liu, and X. Liu, "Tracking your browser with high-performance browser fingerprint recognition model," China Communications, vol. 17, no. 3, pp. 168-175, Mar. 2020, doi: 10.23919/JCC.2020.03.014.

[3] B. P. Nguyen, W. L. Tay, and C. K. Chui, "Robust Biometric Recognition from Palm Depth Images for Gloved Hands," IEEE Transactions on Human-Machine Systems, vol. 45, no. 6, pp. 799-804, Dec. 2015, doi: 10.1109/THMS.2015.2453203.

[4] A. Gangwar and A. Joshi, "DeepIrisNet: Deep iris representation with applications in iris recognition and cross-sensor iris recognition," undefined, vol. 2016-August, pp. 2301-2305, Aug. 2016, doi: 10.1109/ICIP.2016.7532769.

[5] R. He, X. Wu, Z. Sun, and T. Tan, "Wasserstein CNN: Learning Invariant Features for NIR-VIS Face Recognition," IEEE Transactions on Pattern Analysis and Machine Intelligence, vol. 41, no. 7, pp. 1761-1773, Jul. 2019, doi: 10.1109/TPAMI.2018.2842770.

[6] S. Wardoyo, R. Wiryadinata, and R. Sagita, "Sistem Presensi Berbasis Agoritma Eigenface Dengan Metode Principal Component Analysis," Setrum: Sistem Kendali-Tenaga-elektronika-telekomunikasi-komputer, vol. 3, no. 1, pp. 61-68, Mar. 2016, doi: 10.36055/SETRUM.V3I1.498.

[7] Hanif Al Fatta, Rekayasa Sistem Pengenalan Wajah. Yogyakarta: Andi Offset, 2009.

[8] Ari Kurniawan and Marzuki Syahfirin, "Aplikasi Deteksi Objek Menggunakan Histogram of Oriented Gradient Untuk Modul Sistem Cerdas Pada Robot Nao,” Lampung, 2016.

[9] A. Zisserman, "C19 Machine Learning lectures Hilary 2015, Lecture 2: The SVM classifier." 2015.

[10] C. Cortes, V. Vapnik, and L. Saitta, "Support-vector networks," Machine Learning 1995 20:3, vol. 20, no. 3, pp. 273-297, Sep. 1995, doi: 10.1007/BF00994018.

[11] F. Schroff, D. Kalenichenko, and J. Philbin, "FaceNet: A Unified Embedding for Face Recognition and Clustering," Proceedings of the IEEE Computer Society Conference on Computer Vision and Pattern Recognition, vol. 07-12-June-2015, pp. 815-823, Mar. 2015, doi: 10.1109/CVPR.2015.7298682.

[12] Emmanuel Agu, "Digital Image Processing (CS/ECE 545) Lecture 11: Geometric Operations, Comparing Images and Future Directions." Accessed: Dec. 29, 2021. [Online]. Available: https://web.cs.wpi.edu/ emmanuel/courses/cs545/S14/slides/lecture01.p df

[13] Darma Putra Westriningsih, Pengolahan citra digital / Darma Putra, 1st ed. Yogyakarta: Andi, 2010.

[14] D. M. W. Powers and Ailab, "Evaluation: from precision, recall and Fmeasure to ROC, informedness, markedness and correlation," Oct. 2020, Accessed: Dec. 28, 2021. [Online]. Available: https://arxiv.org/abs/2010.16061v1 